\title{
A Comparative Study of the Objects Used in Chinese and Japanese Color Languages
}

\author{
Xiaohang Liu \\ Dalian Neusoft University of Informatin \\ Dalian, China 116023
}

\begin{abstract}
Color language is a powerful field to prove the diversity of language, and the use of color language is a reflection of a country's life culture. The Chinese color language and the Japanese color language use the same Chinese characters, but the use of the object is not necessarily the same. This paper starts from the first study of color language, chooses the social fixed general expression method to carry on the example analysis, explores the similarities and differences of the use object of the Chinese and Japanese color language.
\end{abstract}

\section{Keywords—color language; objects used; comparative study}

\section{INTRODUCTION}

Color is not merely a phenomenon that exists as color. It must be accompanied by things. Therefore, the name of color also relies on scenery or other things. To explore the color and color language of China and Japan is also an important way to study the life values and aesthetic consciousness of Chinese and Japanese. The rudiment of color language comes from the earliest ancient pigment dyeing. The ancient people used the flower, stem, leaf, skin, root or fruit of the plant, and even the soil as the raw material, and picked out some specific things to name the color and became the color language. With the development of society and the progress of the times, color language is more and more abundant. These color words from nature show signs of being sensitive to nature, love for nature and affinity to nature. This fine view of nature is one of the most important characteristics of every nation, as well as the embodiment of its cultural tradition. It can be seen that color and color words are very important to our life. China and Japan, as neighbors, have a long history of friendly exchanges, and coexist in Asia. The cooperation and influence between the two countries is essential. So what is the attitude of the two countries to the experience of nature, especially the use of color words in life? This paper starts with the study of the color language, and selects the general expression methods that are fixed in the society to analyze the similarities and differences of the use of Chinese and Japanese color language.

Color is not only a physical phenomenon, but also plays an important role in the language world. In the language of the world, the color performance of colorful is common. The culture of various nationalities and the understanding of nature through the expression of color, but also show its unique characteristics. The Chinese color language and the
Japanese color language use the same Chinese characters, but the use of the object is not necessarily the same. The use of color language has two benchmarks. One is the absolute benchmark. Because of the human physiological mechanism and cognitive model is not much different, so for the understanding of color, color language use, there is universal. For example: When you see the Chinese flag, we say red and yellow, and when we see the Japanese flag, we say, white and red. There is no dispute. The other is the relative benchmark. Because language has a close connection with its social culture and is influenced by usage habits, the use of color language in each language has its own particularity. For example: When people are frightened, they often use "white" or "pale" in Chinese, while Japanese often use "green" or "plainer".

\section{COLOR LANGUAGE AND BASIC COLOR LANGUAGE}

The research on color language is mainly from three aspects: color, color name and color language, and the "color" and "color name" are not the same thing. So far, the collection of color names is between 300 and 500, of which 20 to 30 are widely used in social life. Although color is rich and varied, the use of color language is different from that of nationalities and regions. 伊藤雅光 (1996), The color-related vocabulary is divided into four categories:

(1)Words that are pure color (Such as：赤、青、金色…) (2) The name of a thing is also a color name, material name, which can be categorized according to color (Such as: 金の 砂、銀の砂…) (3) It's not only a color, but also a concept beyond color (Such as: 銀河、青春、…) (4)Chinese character markings contain color, but the words themselves express other meanings (Such as: 黄昏、銀杏…)

On the basic color language, American linguists Brent Berlin and Paul Kay, 1969, based on the survey of the 98 language in the world, put forward the basic color language theory. The 11 basic colors include white, black, red, green, yellow, blue, brown, pink, purple, orange and grey. "Fig. 1" is a code evolution diagram of the 11 basic color languages that show that in any language, at least two basic color codes are black and white, and if there are third kinds of color, it is red, if there are fourth kinds of green or yellow, and so on. These color words contain the following two characteristics: (1) the fields of basic color vocabularies are different, but the typical colors of focus are consistent among languages. (2) 
The number of basic color words is different among countries, but there is no limit. The most common cases are these 11 kinds of color words.

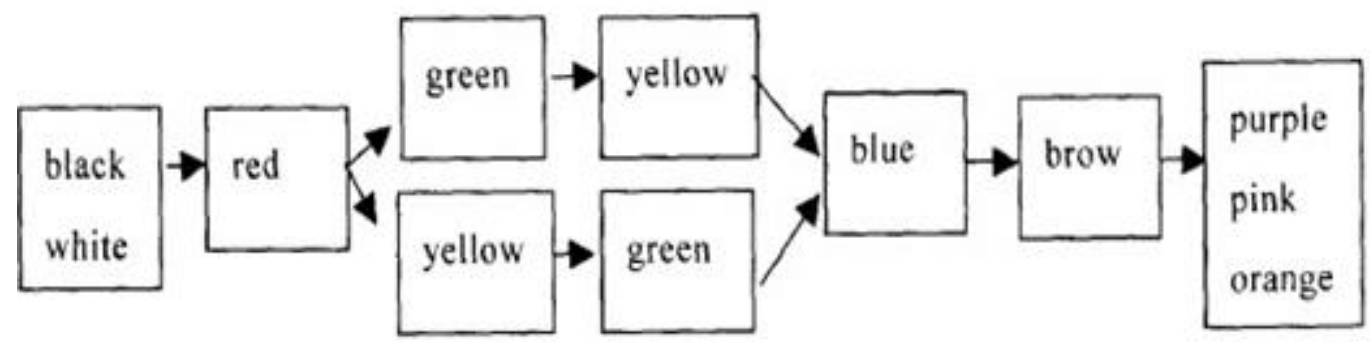

Fig. 1. Basic color code evolution graph (B\&K1969).

大岡信 (1979) points out, The initial basic colors of Japanese are “赤, 黑, 白, 青” Corresponding to the "明, 暗, 顕, 漠" of the color feeling. It shows that these four colors are formed by the Japanese according to the light and dark feeling.

\begin{tabular}{|l|l|l|l|l|}
\hline Color sense & 明 & 暗 & 顕 & 漠 \\
\hline Color & 赤 & 黒 & 白 & 青 \\
\hline
\end{tabular}

Fig. 2. The basic color language of ancient Japan.

The most basic expression of color expression in ancient

China is green, red, yellow, white and black. The five colors

\begin{tabular}{|c|c|c|c|c|c|c|}
\hline 五 & 行 & 木 & 火 & 土 & 金 & 水 \\
\hline 五 & 色 & 青 & 赤 & 黄 & 白 & 黒 \\
\hline 五 & 方 & 東 & 南 & 中央 & 西 & 北 \\
\hline 五 & 時 & 春 & 夏 & 季夏 & 秋 & 冬 \\
\hline 五 & 事 & 貌 & 視 & 思 & 言 & 聴 \\
\hline 五 & 声 & 角 & 徵 & 宮 & 商 & 羽 \\
\hline 五 & 味 & 酸 & 苦 & 甘 & 辛 & 献 \\
\hline 五 & 官 & 目 & 舌 & 口唇 & 草 & 耳 \\
\hline 五 & 常 & 化 & 礼 & 信 & 莪 & 智 \\
\hline 五 & 崴 & 肝 & 心 & 脾 & 肺 & 㫮 \\
\hline 四 & 神 & $\begin{array}{l}\text { 青龍 } \\
\text { 畜龍 }\end{array}$ & $\begin{array}{l}\text { 朱雀 } \\
\text { 風園 }\end{array}$ & & 白虎 & 玄武 \\
\hline+7 & $\mp$ & 甲 乙 & 丙 丁 & 成 己 & 庚 辛 & 壬 癸 \\
\hline+ 二 & & $\begin{array}{l}\text { 寅 } \\
\text { 辰 }\end{array}$ & $\begin{array}{l}\text { 巳 } \text { 午 } \\
\text { 未 }\end{array}$ & $\begin{array}{ll}\text { 辰 } & \text { 成 } \\
\text { \# } & \text { 末 }\end{array}$ & $\begin{array}{l}\text { 申 西 } \\
\text { 成 }\end{array}$ & $\begin{array}{ll}\text { 亥 子 } \\
\text { \# }\end{array}$ \\
\hline 月 (陰厤 & & 三 二 & $\begin{array}{l}\text { 四 } \\
\text { 六 }\end{array}$ & & $\begin{array}{l}\text { 七 } \\
\text { 九 }\end{array}$ & $\begin{array}{l}+ \\
+=\end{array}$ \\
\hline
\end{tabular}

Fig. 3. China's five elements matching Chart.

\section{COMPARISON OF THE OBJECTS USED IN CHINESE AND JAPANESE COLOR LANGUAGE}

The following is a comparison of the similarities and differences between Chinese and Japanese color words, mainly for the use of basic color language examples. This paper does not involve the use of color words in literary expression, but only discusses the general methods of expression which have been fixed in society. correspond to the five elements in ancient China. The five elements of ancient China and the theory of yin and Yang thought that things were originally different, but they kept moving and the "gas" that had energy made the things interrelated and interact in the universe. The five basic color languages is the embodiment of the five elements in the color system. In The Color Beauty of Language, Liu Yunquan pointed out that the influence of the Five Elements Theory on the interpretation of color words is deeper. 
".The Chinese word "黑红" and the Japanese word "赤黑" have different word order, but the meaning is roughly the same, are used to describe a sunburned face. The Japanese words "白い顔" and "青い顔" and "青白い顔" can be translated into "苍白的脸" in Chinese. However, "白い顔" mainly refers to the face of the skin color white, but also refers to illness and other reasons caused by the lack of blood gas. "青い顔" is used to refer to the face of a person who is frightened.

B. Eyes

Chinese

$$
\text { 眼: 白、黑、红、青 }
$$

Japanese

$$
\text { 目: 白、黑、赤青、茶色 }
$$

In Japanese, "白", "黑" and "赤" can exist in the form of " 白目", "黑目", "赤目", or as adjectives. "青" and "茶色" are often used as adjectives, and "茶色の" can also be used in the form of "茶色". Japanese people love "茶色" very much, and are often used to describe similar colors in daily life. The "白 眼" in Chinese refers to the cold eyes. In the etymology, Ruan Ji, the Jin Dynasty scholar of the Seven Sages of the bamboo forest, uses "白眼" for the disliked people or the laity. In contrast, the eyes of the respectable or loved ones are expressed with the "青眼".In Japanese, there are also words like "白目"白眼視", which express cold and contemptuous attitude. In Japanese, there are also "青眼" showing a kind eye. In addition, there is another meaning. "正眼"in kendo is aimed at each other's eyes.In Chinese, "红眼" means anger, jealousy and eye congestion caused by acute keratitis. The three meaning is "red eye". In Japanese, "赤目" has only one meaning, which means eye congestion due to fatigue or disease.

\section{Cattle \\ Chinese 牛: 白、黑、黄 \\ Japanese

$$
\text { 牛: 白、黑、赤 }
$$

In both Chinese and Japanese languages, they are often used as conjunctive modifiers, “白牛”, “黑牛”, “黄牛”,「し ろうし」,「くろうし」,「あかうし」. “黄牛” in Chinese is similar to “赤牛” in Japanese.

\section{Bean}

Chinese

$$
\text { 豆: 白、黑、红、绿、青、黄 }
$$

Japanese

$$
\text { 豆: 白、黑、緑、青 }
$$

In Japanese, synthetic words are used in the form of "しろ まめ""くろまめ""あおまめ", and "緑豆" are used as Chinese words.The " $\mathrm{r}$ 红豆" in Chinese corresponds to "小豆" in Japanese, and the "s 黄豆" in Chinese corresponds to the "大豆 " in Japanese. In Chinese, there are "小豆" and "大豆", which are the same as those in Japanese.

\section{E. Land}

$$
\begin{array}{ll}
\text { Chinese } & \text { 土: 白、黑、红、黄 } \\
\text { Japanese 土: 黑、紅、緑、黄、茶色 }
\end{array}
$$

Different countries have different geographical conditions, and the color expression of soil is also different.
The distribution of land in China is across the subtropics, temperate and subtropical zones, and the soil color is more. The territory of Japan is mainly in temperate zone, with less soil type.Among them, there are "黑土" in Chinese and Japanese, and the concept of "红土" and "黄土" are basically the same.The "白土" in Chinese refers to the "制陶用土".The " 緑土" in Japanese refers to the flourishing zone of timber, rather than the color of the land. And the "茶色" to describe the soil is also unique in Japanese.

\section{F. Traffic Lights \\ Chinese 交通信号灯: 红、绿、黄 \\ Japanese 信号: 赤青、黄}

In Japanese, the "赤信号" and "青信号" are used in the form of the idiom, but the "黄信号" is rarely seen, but is expressed in the form of "y 黄色の信号" or "黄色い信号".The " 绿灯" in Chinese corresponds with the "青信号" in Japanese.

\section{THE ANALYSIS OF THE SIMILARITIES AND DIFFERENCES OF THE OBJECTS USED IN CHINESE AND JAPANESE COLOR LANGUAGE}

\section{A. The Reason for the Same Objects Used}

1) Human knowledge of color is roughly the same: Color is a physical phenomenon. When the light comes to the object, it makes the visual nerve experience. The physical cognition of color is basically the same between Chinese and Japanese people. For example, the snow is white and black, and the leaves are green. Because of this, the usage of many color words is the same.

2) Influenced by Chinese traditional culture: A narrow strip of water between China and Japan, since ancient times, frequent economic and cultural exchanges, and mutual influence. In Chinese ancient Chinese, the "白眼" is used for the dislike people or the laity. In contrast, for the respectable or liked people, the "青眼" is used to express the kindly eyes. Japan affected China culture; there are also "白い目" "青い目".

\section{B. The Reason for the Different Objects Used}

1) The social and cultural differences between China and Japan: Though there is a long history of language and cultural exchanges between China and Japan, each country has its own culture of every country. Kentoshi RongXi in Chinese after learning the tea ceremony brought to Japan, and Japan carried it forward. Japanese people like tea very much. They can't live without tea. The "和敬清寂" in the tea ceremony reflects the Japanese's attitude towards life. Japanese people like to use "茶色" to describe things. For example, in Japanese, "茶色" is often used in the description of the color of the land and eyes. This is very rare in Chinese.

2) Different natural environment between China and Japan: The geographical conditions of different countries are different. The territory of China is large and distributes across the subtropical zone, temperate zone and sub cold 
zone. Japan is a narrow island country, mainly in temperate zone. The geographical environment of the two countries is different, resulting in different natural features and crops. China describes the number of color words in beans more than that in Japan, mainly because the beans produced in China are more abundant. In addition, although Japan has a small land area, it attaches great importance to the forest coverage, so the "緑土" in Japanese refers to the area of wood and wood, which does not mean the color of the land.

3) The remnant of ancient Chinese in Japanese: There are many similar uses between Chinese and Japanese vocabulary, but with the development of the times, there are also many changes.For example, although " 青" is transmitted from China to Japan, the semantic meaning of " 青" in modern Chinese is basically "绿色", for example, "青山 " and "青松", but in modern Japanese "青" is mainly meaning "蓝色" and "绿色, 白色".Green signal lamp is called "青信号" in Japanese. When a person is frightened, he looks pale and uses "青い顔" to express.

\section{CONCLUSION}

In summary, it is not difficult to see that the Chinese and Japanese perceptions of color are roughly the same. On the one hand, they belong to the Chinese character circle, and the two countries have a long history of communication; on the other hand, China and Japan have a similar place in natural geography. However, because the basic color language items are basically the same in the two countries, their usage is quite similar. The reasons for the differences in the use of color language are mainly influenced by their own culture, history, geography and usage habits. The use of color language is mutual influence in Chinese and Japanese, but there is no difference between them.

\section{REFERENCES}

[1] Liu Yunquan. The beauty of color in language[M]. Hefei: Anhui Education Press, 1990: 148-149.

[2] Liu Xiaohang. A comparative study of Chinese and Japanese color language_-Take "白" as the center[D]. Liaoning Normal University, 2008

[3] Liu Xiaohang. "白 " in Japanese and its cultural significance[J]. Japanese knowledge, 2012(1), 26-27.

[4] Liang Baowei. A tentative study of the theoretical framework of the meaning contrast between Chinese and Japanese color words[J]. Japanese learning and research, 2006(3), 34-37. 